\title{
Optimal Allocation of the Irrigation Water Through a Non Linear Mathematical Model
}

\author{
Pietro Rubino ${ }^{1 *}$, Maurizia Catalano ${ }^{1}$, Roberta $_{\mathrm{Rana}^{2}}$, Angelo Caliandro ${ }^{1}$ \\ ${ }^{1}$ Dipartimento di Scienze delle Produzioni Vegetali, Università di Bari \\ Via Amendola 165/A, 70126 Bari \\ ${ }^{2}$ Collaboratore esterno
}

Received: 29 March 2008. Accepted: 16 July 2008.

\begin{abstract}
A study on the optimal allocation of the irrigation water among 9 crops (autumnal and spring sugar beet, spring and summer grain maize, dry and shell bean, eggplant, pepper and processing tomato) has been carried out, utilizing experimental data of yield response to irrigation obtained in different years in Southern Italy (Policoro MT, $40^{\circ}$ 12' Northern Lat.; $16^{\circ} 40^{\prime}$ Western Long.). Fitting Mitscherlich's equation modified by Giardini and Borin to the experimental data of each crop, the curve response parameters have been calculated: $\mathrm{A}=$ maximum achievable yield in the considered area $\left(\mathrm{t} \mathrm{ha}^{-1}\right) ; \mathrm{b}=$ extra-irrigation water used by the crop $\left(\mathrm{m}^{3} \mathrm{ha}^{-1}\right)$; $\mathrm{c}=$ water action factor $\left(\mathrm{ha} \mathrm{m}^{-3}\right)$; $\mathrm{K}$, calculated only for tomato crop. ,decreasing factor due to the water exceeding the optimal seasonal irrigation volume $\left(100 \%\right.$ of the Crop Maximum Evapotranspiration less effective rainfall, ETM $\left.\mathrm{I}_{\mathrm{r}}\right)$. The A values, using the prices of the agricultural produces and the irrigation water tariffs applied by the Consorzio Irriguo della Capitanata, have been converted in Value of Production (VP) less the fixed and variable irrigation costs $\left(\mathrm{VP}_{\text {lic }}\right)$. The equation parameters were used in a non linear mathematical model written in GAMS (General Algebraic Modelling System), in order to define the best irrigation water allocation amongst the 9 crops across the entire range of water availability and the volume of maximum economical advantage, hypothesising that each crop occupied the same surface (1 ha). This seasonal irrigation volume, that corresponded to the maximum total $\mathrm{VP}_{\text {lic }}$, was equal to $37000 \mathrm{~m}^{3}$. Moreover, the model allowed to define the best irrigation water distribution among the crops also for total available volumes lower than that of maximum economical advantage $\left(37000 \mathrm{~m}^{3}\right)$.

Finally, it has been underlined that the vegetable crops should be irrigated with seasonal irrigation volumes equal to $100 \%$ of the ETM, whereas the summer and spring maize and the autumnal and spring sugar beet with volumes equal to $78 ; 62 ; 48$ and $41 \%$ of the ETM, respectively.

This research work has confirmed the validity of the model, that can also be adopted to study other yield factors.
\end{abstract}

Key-words: Water allocation, herbaceous crops, mathematical model, GAMS procedure.

\section{Introduction}

There is no life without water; the water is an essential good for all the human activities and never, like in this historical moment, the water resources represent a primary patrimony for the human being.

The good water supplies are not inexhaustible, so, it is necessary to preserve, control and even increase their amount through an efficient management.

It is also important to monitor the water quality alterations because they can cause damages to human health and to other living beings. The water, for that, is considered like a limited and valuable good to apply in a correct and ra- tional way, both to avoid wastes and to not increase the cost of its use. This last cost markedly affects the yield costs of all goods because the water is an indispensable yield factor.

Among different uses, civil industrial and agricultural, the latter are more penalized specially in situations with poor water availability, frequent in warm and arid areas. In fact, in these areas, characterized by an annual rainfall varying from 250 to $500 \mathrm{~mm}$, economically acceptable agricultural yields can be obtained only with irrigation during part or total cropping period. In extreme situations, in the desert areas with less than $250 \mathrm{~mm}$, irrigation is not even feasible because the scarce water resources avail- 
able are employed almost exclusively for drinkable use. It is known that actually in the world about the $60 \%$ of the available water resources is employed in agriculture mainly for irrigation; this percentage, higher in the arid zones, does not satisfy agricultural requirements and moreover will decrease in the next future because of the increasing water requirements for civil and industrial uses.

For the reasons so far illustrated, many irrigation researches, in all over the world, have been studying how to increase the water use efficiency (WUE) (Steduto et al., 1996) that in some areas is still very low (almost $50 \%$ or less) and that, instead, could be improved by adopting engineering and agronomical strategies aimed at enhancing the efficiency of the single components of the total efficiency (Hsiao, 2005).

Among the possible strategies to be adopted in the rational management of the irrigation water resource, principally in water scarcity conditions, the most important one is the irrigation water allocation, i.e. the best water distribution among different crops considered all together in the same environment in order to maximize their profit. The yield response expressed in terms of Value of Production (VP) less the fixed and variable irrigation costs $\left(\mathrm{VP}_{\text {lic }}\right)$ permits to formulate some technical and economic considerations both at farm and district scale.

The economical aspects of the water irrigation use are equal to those of each other factor of production dividable in doses (Cavazza, 1968).

One of the methods to formulate an irrigation profit evaluation of a single crop is to calculate yield response curve varying the seasonal irrigation volume starting from reliable experimental data. The seasonal volume corresponding to maximum yield, rarely matches the one that gives the best profit.

To evaluate the best irrigation profit of more crops and optimize the total available water resource allocation it is necessary to have the single crop yield response curves to irrigation in order to analyze them all together.

Many regression models have been studied to calculate the response curves to a production factor (Boguslawski, 1981; Mitscherlich, 1909; Giardini and Borin, 1985; Vannella, 1982) that enclose the most information of the fitted experimental data in their non linear parameters
(Rubino and Vannella, 1989), to which a biological and agronomical meaning can be associated.

The importance of this study is highlighted by the high number of researches performed in order to develop optimization models which solve the allocation of water resources maximizing farmers benefits (Gorantiwar and Smout, 2006; Shangguan et al., 2002; Reca et al., 2001; Al Weshah, 2000).

The innovative idea of this study has been to join the irrigation yield response curves (expressed in economical terms) with mathematical modelling methodologies in order to provide a tool able to optimize the allocation of the irrigation water among crops grown in the same area. This means to allocate a total available irrigation volume such as to maximize the total yield of the whole area and not that of the single crop, under constraints imposed to the system.

In this first paper, an example of irrigation water optimal allocation among 9 herbaceous crops is reported, considering that a unit area of one hectare has been assigned to each crop.

The equation of Mitscherlich modified by Giardini and Borin has been chosen among those previously reported, to describe the yield response to irrigation water, whereas to optimize the allocation of the water resource, the GAMS (General Algebraic Modelling System) language has been used (Brooke et al., 1992).

\section{Materials and methods}

\section{Crop data}

To realize this study experimental data have been gathered from researches carried out in the experimental farm of Bari University, located in Policoro area ( $40^{\circ}$ and $12^{\prime}$ ' Northern Lat. and $16^{\circ}$ and $40^{\prime}$ Eastern Long.).

The field researches have been carried out in different years on the following herbaceous crops:processing tomato (Rubino and Vannella, 1989); spring maize (Caliandro et al., 1983); summer maize (Quaglietta Chiarandà et al., 1982); dry bean (Rubino and Tarantino, 1981); shell bean (Tarantino et al., 1982); autumnal sugar beet (Cucci et al., 1989); spring sugar beet (Caliandro and De Caro, 1973); eggplant (Linsalata and De Caro, 1977); pepper (Caliandro and De Caro, 1973). 
For each crop, the three parameters Mitscherlich equation (A, b, c) ${ }^{1}$ modified by Giardini and Borin (Giardini et al., 1985) has been fitted to the experimental data of yield, varying by increasing the seasonal irrigation volume up to the maximum technical one $(100 \%$ of the maximum evapotranspiration of the crop, ETM), and the yield response curve parameters have been calculated. For processing tomato only, the four parameters Mitscherlich equation $(\mathrm{A}, \mathrm{b}, \mathrm{c}, \mathrm{K})^{2}$, as modified by Giardini and Borin, has been adopted. The latter equation, indeed, contains in addition the $\mathrm{K}$ parameter, that represents the depression coefficient of the yield; that diminishes with seasonal irrigation volumes major than the crop water requirements.

The optimal allocation of the water resource aims to maximize the profit of a farm or a district; to achieve such objective, the values of maximum yield estimated by Mitscherlich function in $\mathrm{t} \mathrm{ha}^{-1}$ (A parameter) have been converted in Value of Production (VP) less the fixed and variable irrigation costs $\left(\mathrm{VP}_{\text {lic }}\right)$, considering the actual prizes of the agriculture products. After converting the A parameter in euro (VP), the value of the other parameters (b, $\mathrm{c}$, and $\mathrm{K}$ ) of Mitscherlich equation has not changed, as well as their agronomical meaning.

To determine the best water allocation among the tested crops, a non-linear mathematical model written in GAMS has been adopted, because it permits to resolve multidimensional problems with simplicity and rapidity.

\section{The mathematical model}

An analysis was carried out in order to define a methodological approach that, starting from the mathematical formalization of the relationships among variables and parameters involved, could optimize water allocation by using the potentiality of already codified algorithms. The sum of the existing relationships among variables and parameters represents the skeleton of the computer model, while the values associated to each parameter are the data of the problem, depending on the particular study area and also susceptible of modifications. Nevertheless, the model structure could be modified too, in order to better adapt to the investigated situation, i.e. to take into account other constrains to the productivity.

It is important to point out that complexity of water use optimization problems increases when the number of crops that contemporarily grow up in the study area is so large to determine a conflict in using limited total resources (water and/or arable surface).

In order to develop flexible models, a particular computing system has been used, which consists of an integrated system of high performances solvers combined to elements of relational theory of databases and mathematical programming. This system, widely used to solve management problems in economics and engineering, is called General Algebraic Modelling System (GAMS) (Broke et al., 1992). The GAMS procedure has been adopted not only for the immediacy and relative simplicity with which is possible to formulate multidimensional problems, but also because, unlike other programs, it allows modifications in the data without interfering with the logical structure of the problem.

Yield response data for each crops have been used to evaluate the parameters of Mitscherlich equation modified by Giardini and Borin, which represent the input of the model. It has to be pointed out that the schematization of the problem and the degree of accuracy of solutions largely depends on the reliability of the experimental data needed to formulate the constrained optimization problem.

The decision variables of the investigated problem are the irrigation volumes totally applied to each crop and represent the components of the $\mathrm{n}$ dimension vector $\left(\mathrm{V}_{1}, \mathrm{~V}_{2}, \mathrm{~V}_{\mathrm{n}}\right)$, where the subscript $\mathrm{p}=1,2 \mathrm{n}$, indicates the crop to which is applied each volume.

In this study 9 crops have been considered (processing tomato, spring and summer maize, dry and shell bean, autumnal and spring sugar

\footnotetext{
$1 \quad \mathrm{y}=\mathrm{A}\left[1-10^{-\mathrm{c}(\mathrm{b}+\mathrm{x})}\right] /\left[1+10^{1-\mathrm{c}(\mathrm{b}+\mathrm{x})}\right]$ $\mathrm{y}=\mathrm{A}\left[1-10^{-\mathrm{c}(\mathrm{b}+\mathrm{x})}\right] \cdot\left[10^{-\mathrm{k}(\mathrm{b}+\mathrm{x})^{2}}\right] /\left[1+10^{1-\mathrm{c}(\mathrm{b}+\mathrm{x})}\right]$

where: $y$ is the yield, in $\mathrm{tha}^{-1}$;

$A$ is the maximum potential yield, in $\mathrm{t} \mathrm{ha}^{-1}$;

$c$ is the coefficient of increase, indicating the rapidity of achievement of the maximum yield, in ha $\mathrm{m}^{-3}$;

$k$ is the coefficient of depression, indicating the tendency of the yield to decrease after the achievement of the maximum value, in $\left(\text { ha } \mathrm{m}^{-3}\right)^{2}$;

$b$ is the volume of water available per ha for the crop in natural conditions, in $\mathrm{m}^{3} \mathrm{ha}^{-1}$;

$x$ is the volume of water applied per ha under specific experimental conditions, in $\mathrm{m}^{3} \mathrm{ha}^{-1}$.
} 
beet, eggplant and pepper), each of them characterised by a specific yield response to seasonal irrigation water volume.

Seasonal irrigation volumes $\left(\mathrm{V}_{1}, \mathrm{~V}_{2}, \mathrm{~V}_{\mathrm{n}}\right)$ are the independent variables of the problem, as crop yield and the corresponding Value of Production (VP) vary according to the less/more amount of water given to the different crops. In this study, a simplification is made by modelling only these variables $\left(\mathrm{V}_{1}, \mathrm{~V}_{2}, \mathrm{~V}_{\mathrm{n}}\right)$; in this way it has been possible to evaluate the relation occurring between production and irrigation volume, when all the other parameters are fixed.

To focalize this aspect, all the other elements of the system (i.e. possible variation of the assigned surface to each crop, fixed and variable costs, variability of price and production costs, and so on) have been omitted, while considering water resource consumption as the only condition imposed to the system.

On the other hand, crops production and production values can be considered as "dependent variables" of the problem, as they can be quantified from the yield response curves for assigned values of irrigation volume.

The aim of the modelling process is to optimize the allocation of seasonal irrigation volumes among 9 different crops. As allocation process among the different crops becomes more difficult where water scarcity occurs, that is when all water requirement can not be simultaneously satisfied, the computation has been reiterated, considering different available volumes, varying from 10 to $100 \%$ of total estimated water requirement, firstly obtained by taking into account the yield response curves.

In this way, an evaluation was carried out of the variation in optimal distribution of water among the crops with decreasing water deficit conditions.

To reach this objective, a physical constraint has been considered, i.e. the total amount of water allocated to all the given crops can not exceed the total available volume.

In addition, an economic constrain, to account for the variation of the irrigation costs in relation to the water amount applied, has been considered.

To correctly model this last constrain, it is necessary to consider the water tariff adopted by "Consorzio Irriguo". In this example, tariff varies with the given seasonal irrigation volume, as shown in Figure 1. From the mathematical point of view, this constraint can be modelled by imposing that water price changes when water consumption becomes more than $2000 \mathrm{~m}^{3} \mathrm{ha}^{-1}$ and that the same occurs when the limit of 3000 $\mathrm{m}^{3} \mathrm{ha}^{-1}$ is overcome.

The last assumption made in the model was to fix the total surface assigned to each crop, to the unitary value of 1 hectare.

With those all hypothesis, the model consists of 4 equations (an objective function, a physical constrain, two economical constrains). The unknowns are 9 (or 27 considering that the volume $\mathrm{Vp}$ is the sum of 3 different volumes, each associated to a given water price).

The $\mathrm{m}$ constraints are less than the $\mathrm{n}$ decision variables, so determining an infinity of nm possible solutions $\left(\infty^{\mathrm{n}-\mathrm{m}}\right)$; among them, the algorithm finds the optimal solution that can be a local or a global optimum. Each solution, composed by a vector of values assigned to each variables, represents a possible solution. Therefore, the global solution of the problem consists in finding the unique vector $\mathrm{V}\left(\mathrm{V}_{1}, \mathrm{~V}_{2}, \mathrm{~V}_{\mathrm{n}}\right)$ that maximizes the Value of Production less the fixed and variable irrigation costs $\left(\mathrm{VP}_{\text {lic }}\right)$, evaluated as algebraic summation of the $\mathrm{VP}_{\text {lic }}$ of each crop studied.

As the relation between the $\mathrm{VP}_{\text {lic }}$ and the volume $\mathrm{Vp}$ is non linear, the programming model adopted is a non linear mathematical model. Afterwards, the objective function and the constrains of the investigated problem are described.

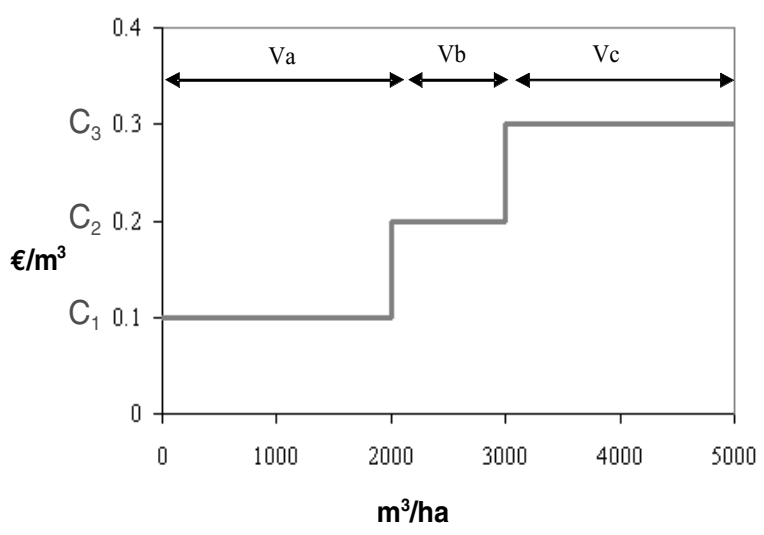

Figure 1. Water tariffs vs irrigation water volume. 


\section{Objective function}

The objective function maximizes the economical profitability of the crops grown in a area $(\mathrm{Z}=$ Production Value (VP), Production Value less the fixed and variable irrigation costs $\left(\mathrm{VP}_{\mathrm{lic}}\right)$, Gross Margin (GM) and so on), assuming that the total water volume available for that area is known.

$$
\begin{gathered}
\mathrm{Z}=\mathrm{VP}_{\text {lic }}=\mathrm{A}_{\mathrm{p}} \Sigma_{\mathrm{p}} \cdot \mathrm{VP}_{\mathrm{p}}-\mathrm{A}_{\mathrm{p}} \Sigma_{\mathrm{p}} \mathrm{C}_{\text {fixed }}- \\
\mathrm{A}_{\mathrm{p}} \cdot \Sigma\left(\mathrm{C}_{\mathrm{var}} \cdot \mathrm{V}_{\mathrm{p}}\right)
\end{gathered}
$$

where:

VPp is the Production Value of the single crop, obtained by applying the equation of Mitscherlich modified by Giardini and Borin, as previously described;

$\mathrm{VP}_{\text {lic }}$ is the Production Value less the fixed and variable irrigation costs;

$A_{p} \quad$ is the surface assigned to each crop (in this example $A_{p}=1$ ha);

$\mathrm{C}_{\text {fixed }}$ are the fixed costs, varying with the surface equipped for irrigation;

$\mathrm{C}_{\mathrm{var}}$ are the variable costs, varying with the applied irrigation volume.

In this example the only independent variable is the vector $\left(\mathrm{V}_{1}, \mathrm{~V}_{2}, \mathrm{~V}_{\mathrm{n}}\right)$; that is because a fixed and unitary value (1 ha) was attributed to the value of surface allocated to each crop.

\section{Constraints}

The physical constraints express the requirement that the total amount of water volumes allocated to different crop is lower or at most equal to the total available volume. Such condition can be explained by the following equation:

$$
\Sigma \mathrm{V}_{\mathrm{p}}<=\mathrm{V}_{\text {available }}
$$

where:

$\mathrm{V}_{\mathrm{p}} \quad$ is the irrigation volume corresponding to a certain Production Value $\mathrm{VP}_{\mathrm{p}}$, for each crop considered in the model;

$\mathrm{V}_{\text {available }}$ is the total water volume available for the whole area.

The application of the model has been reiterated in order to evaluate how water allocation changes when total available volumes vary from 1000 to $50000 \mathrm{~m}^{3}$. In this way, a wide range of water availability in the district has been examined.
On the other hand, the economical constrains allow to model the functional relationship between variable costs and the irrigation volume that must be applied to obtain a certain $\mathrm{VP}_{\text {licp }}$. In order to model this condition, the hypothesis, almost always verified, was made that the district management is based on the tariff that varies with the quantity of water applied to each hectare of irrigated surface, included the fixed costs of the irrigation plants.

This quantity, as shown in Figure 1, is in relation to the irrigation water used by each crop and it is expressed by the following analytical conditions:

$$
\mathrm{V}_{\mathrm{a}}+\mathrm{V}_{\mathrm{b}}+\mathrm{V}_{\mathrm{c}}=\mathrm{V}_{\text {used }}=\Sigma \mathrm{V}_{\mathrm{p}}<=\mathrm{V}_{\text {available }}
$$

where $V_{a}, V_{b}, V_{c}$ represent the three water volumes in which the $\mathrm{V}_{\text {used }}$ is ideally split on the basis of the water cost, considering

$$
\mathrm{V}_{\mathrm{a}}=\Sigma \mathrm{V}_{\mathrm{a}, \mathrm{p}}, \mathrm{V}_{\mathrm{b}}=\Sigma \mathrm{V}_{\mathrm{b}, \mathrm{p}}, \mathrm{V}_{\mathrm{c}}=\Sigma \mathrm{V}_{\mathrm{c}, \mathrm{p}}
$$

The condition that $\mathrm{V}_{\mathrm{a}, \mathrm{p}}$ is always inferior or equal to $\mathrm{V}_{\mathrm{c} 1}\left(2000 \mathrm{~m}^{3}\right)$ maximum volume to which corresponds a unitary price $\mathrm{C}_{1}\left(\mathrm{euro} / \mathrm{m}^{3}\right)$ and that $\mathrm{V}_{\mathrm{b}, \mathrm{p}}$ is always between 2000 and 3000 $\mathrm{m}^{3}$ (i.e. $\mathrm{V}_{\mathrm{a}, \mathrm{p}}+\mathrm{V}_{\mathrm{b}, \mathrm{p}}\left(2000-3000 \mathrm{~m}^{3}\right)$, maximum volume in which the unitary cost $\left(\mathrm{euro} / \mathrm{m}^{3}\right)$ is $\mathrm{C}_{2}$, must be observed.

In synthesis:

$$
\begin{aligned}
& \mathrm{V}_{\mathrm{a}, \mathrm{p}}<=2000 \mathrm{~m}^{3} \\
& \mathrm{~V}_{\mathrm{b}, \mathrm{p}}<=1000 \mathrm{~m}^{3}
\end{aligned}
$$

The splitting of $\mathrm{V}_{\text {used }}$ in the three volumes $\mathrm{V}_{\mathrm{a}}, \mathrm{V}_{\mathrm{b}}$ and $\mathrm{V}_{\mathrm{c}}$ is obtained during the optimization process.

A further application of the model could be the analysis of the water allocation optimization, while varying also the surfaces assigned to the single crops.

\section{Results}

Fitting the equation of Mitscherlich as modified by Giardini and Borin to yield data of the nine examined crops, the parameters useful for the non linear programming model have been calculated (Tab. 1). The adopted equation fitted well the experimental data as it is possible to see from the high $\mathrm{R}^{2}$ values and from the low and not significant $\chi^{2}$ values. 
Table 1. Parameters of Mitscherlich equation modified by Giardini and Borin (A, b, c, k), Value of Production (VP), $\chi^{2}$ and $\mathrm{R}^{2}$ values and total rainfall recorded over each crop cycle (average across the years) for the examined crops.

\begin{tabular}{|c|c|c|c|c|c|c|c|c|c|}
\hline Crops & $\begin{array}{c}\text { A } \\
\left(\mathrm{t} * \mathrm{ha}^{-1}\right)\end{array}$ & $\begin{array}{l}\mathrm{VP}_{\max } \\
\left(€ * \mathrm{ha}^{-1}\right)\end{array}$ & $\begin{array}{c}\mathrm{b} \\
\left(\mathrm{m}^{3 *} \mathrm{ha}^{-1}\right)\end{array}$ & $\begin{array}{c}\mathrm{c} \\
\left(\mathrm{ha}^{*} \mathrm{~m}^{-3}\right) \\
* 10^{-4}\end{array}$ & $\begin{array}{c}\mathrm{K} \\
\left(\mathrm{ha}^{*} \mathrm{~m}^{-3}\right)^{2} \\
* 10^{-9}\end{array}$ & $\begin{array}{c}\text { Total } \\
\text { observations } \\
\text { number }\end{array}$ & $\begin{array}{c}\chi^{2} \\
\text { values }\end{array}$ & $\begin{array}{c}\mathrm{R}^{2} \\
\text { values }\end{array}$ & $\begin{array}{l}\text { Total rainfall } \\
\text { recorded } \\
\text { over the crop } \\
\text { cycle }(\mathrm{mm})\end{array}$ \\
\hline $\begin{array}{l}\text { Eggplant } \\
\text { Autumnal }\end{array}$ & 45.81 & 18323 & 2500.0 & 3.76 & 0 & 15 & 10.57 & 0.98 & 150 \\
\hline $\begin{array}{l}\text { sugar beet } \\
\text { Spring sugar }\end{array}$ & 84.13 & 3485 & 5942.0 & 2.14 & 0 & 15 & 15.17 & 0.99 & 436 \\
\hline beet & 69.17 & 2865 & 2850.0 & 3.16 & 0 & 20 & 17.48 & 0.99 & 125 \\
\hline Dry bean & 3.56 & 2846 & 883.7 & 4.20 & 0 & 10 & 1.09 & 0.96 & 50 \\
\hline Fresh bean & 8.00 & 5600 & 22.4 & 5.37 & 0 & 10 & 0.84 & 0.98 & 50 \\
\hline Summer maize & 8.70 & 1131 & 656.8 & 4.58 & 0 & 17 & 1.75 & 0.99 & 87 \\
\hline Spring maize & 11.65 & 1508 & 798 & 4.91 & 0 & 10 & 2.31 & 0.99 & 109 \\
\hline Pepper & 43.10 & 22627 & 211.0 & 4.07 & 0 & 10 & 16.55 & 0.98 & 55 \\
\hline $\begin{array}{l}\text { Processing } \\
\text { tomato }\end{array}$ & 101.40 & 24174 & 1945.2 & 2.71 & 1.74 & 20 & 12.60 & 0.99 & 71 \\
\hline
\end{tabular}

From the table it can be seen that the maximum Value of Production $\left(\mathrm{VP}_{\max }\right)$ obtainable in the examined area, corresponding to A parameter multiplied by the unitary market prices (euro/ton), has been the highest for drip-irrigated processing tomato crop and equal to 24210 euro; minor for pepper (22598 euro), eggplant (18323 euro) and shell bean (7000 euro) up to the lowest value of 1131 euro for the summer maize.

The $b$ parameter, or the available water volume utilized by the crop in natural condition (beyond that applied by irrigation), has varied from a maximum value of $5942 \mathrm{~m}^{3} \mathrm{ha}^{-1}$ for the autumnal sugar beet to a minimum one of 22.4 $\mathrm{m}^{3} \mathrm{ha}^{-1}$ for fresh bean; the highest values have been recorded for autumnal and spring sugar beet and eggplant because they took advantage from the rainfalls recorded during their crop cycle, which were, respectively, equal to 436,125 , $150 \mathrm{~mm}$, and soil moisture at sowing or planting time.

The c parameter has ranged from the highest value of $5.37 * 10^{-4} \mathrm{ha} \cdot \mathrm{m}^{-3}$ for fresh bean, highlighting the high response rate of the crops to irrigation water, to the lowest one of $2.14^{*} 10^{-4}$ $\mathrm{ha} \cdot \mathrm{m}^{-3}$ for autumnal sugar beet.

The reduction coefficient of the yield $(\mathrm{K})$, calculated only for processing tomato crop, has resulted equal to $1.823 * 10^{-9}\left(\mathrm{ha}^{-3} \mathrm{~m}^{-3}\right)^{2}$; this low $\mathrm{K}$ value indicates that even increasing the seasonal irrigation volume up to $160 \%$ of ETM the yield decrease is of a low amount.

The results obtained by applying the model written in GAMS, through which the available total volume $\left(\mathrm{V}_{\text {available }}\right)$ has been made vary from 1000 to $50000 \mathrm{~m}^{3}$ for the examined surface of nine hectares, have permitted to determine the optimal irrigation volume to supply to the examined crops, equal to $37000 \mathrm{~m}^{3}$ (for the whole surface) to which corresponds the highest Value of Production less the fixed and variable irrigation costs $\left(\mathrm{VP}_{\text {lic }}\right)$ reported in figure 2.

Particularly, the $37000 \mathrm{~m}^{3}$ of available irrigation water have been split among the different crops. The optimum volumes resulted equal to $7061 \mathrm{~m}^{3} \mathrm{ha}^{-1}$ for pepper, $5568 \mathrm{~m}^{3} \mathrm{ha}^{-1}$ for processing tomato, $4793 \mathrm{~m}^{3} \mathrm{ha}^{-1}$ for eggplant, 4374 $\mathrm{m}^{3} \mathrm{ha}^{-1}$ for shell bean, $3622 \mathrm{~m}^{3} \mathrm{ha}^{-1}$ for dry bean;

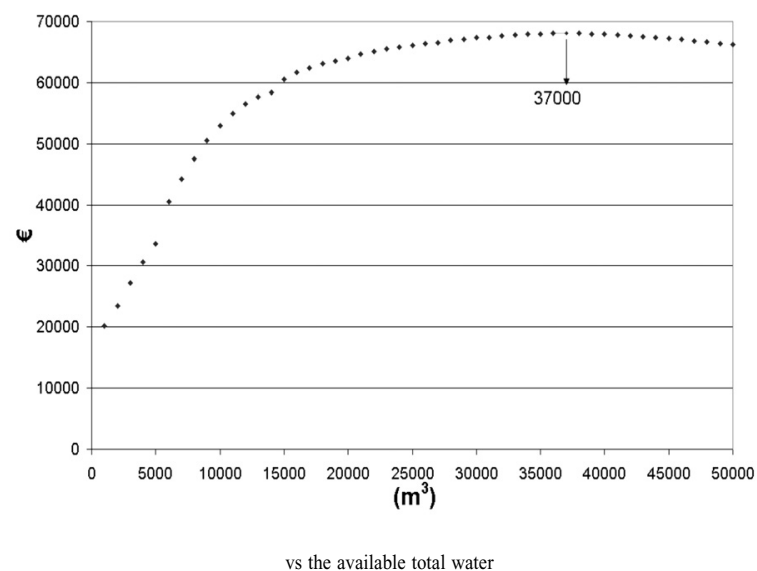

Figure 2. Value of Production less the fixed and variable costs (VPlic) vs the available total water volume (ATWV). The highest value of VPlic (68098 euro) corresponds to a ATWV of $37000 \mathrm{~m}^{3}$. 
$3000 \mathrm{~m}^{3}$ ha $^{-1}$ for spring maize and sugar beet, $2879 \mathrm{~m}^{3} \mathrm{ha}^{-1}$ for summer maize, $2703 \mathrm{~m}^{3} \mathrm{ha}^{-1}$ for autumnal sugar beet (Fig. 3).

In order to give some more detailed descriptions on the water allocation among the 9 examined crops in Figure 4, the optimal division of the irrigation water to varying the available total volume $\left(\mathrm{V}_{\text {available }}\right)$ is visualized, starting from a minimum value of 1000 up to the optimal value, calculated by the model, of $37000 \mathrm{~m}^{3}$.

The irrigation volumes addressed to each crop have been expressed in percent of the available total volume, to better underline the amount of water calculated through the model for each crop, as reported in Figure 3. The percentages attributed to the vegetable crops varied from $19.1 \%$ to $9.8 \%$; but from 8.1 to 7.3 for the other crops (Fig. 5).

Therefore the available total irrigation water partition made by GAMS attributed to the vegetable crops (pepper, processing tomato, eggplant, shell bean and dry bean) seasonal irrigation volumes higher than those attributed to the other crops.

Because such volumes refer to different years and different water requirements crops, in order to make them comparable, they have been converted in percentage of the optimal technical irrigation volume (crop maximum evapotranspiration less the effective rainfall, $\mathrm{ETM}_{\mathrm{lr}}$ ). From Figure 6 it can be seen that the seasonal irrigation volume of the maximum economical advantage is equal to: $100 \%$ of the $\mathrm{ETM}_{\mathrm{lr}}$ for vegetable crops; to $78 ; 62 ; 48$; and $41 \%$ of $\mathrm{ETM}_{\mathrm{lr}}$

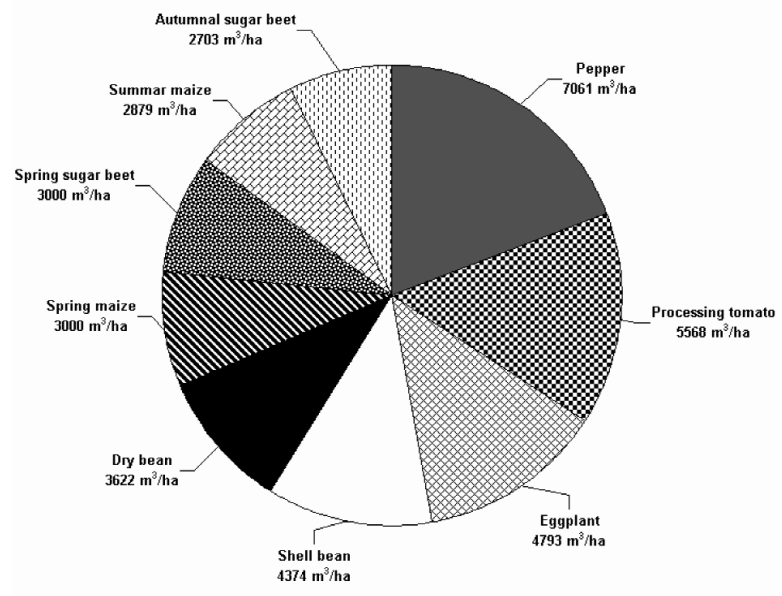

Figure 3. Allocation of the available total water volume of $37000 \mathrm{~m}^{3}$ among the examined nine crops.

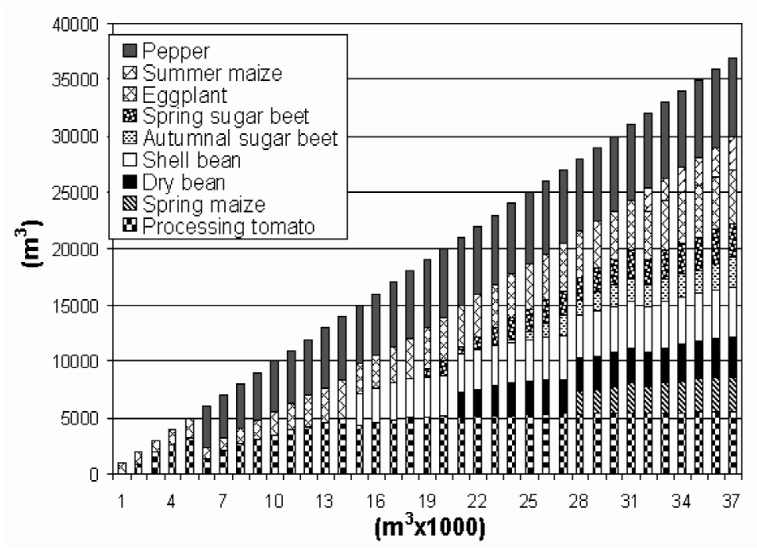

Figure 4. Seasonal irrigation volumes allocated among crops across the entire range of water availability $\left(0-37000 \mathrm{~m}^{3}\right)$.

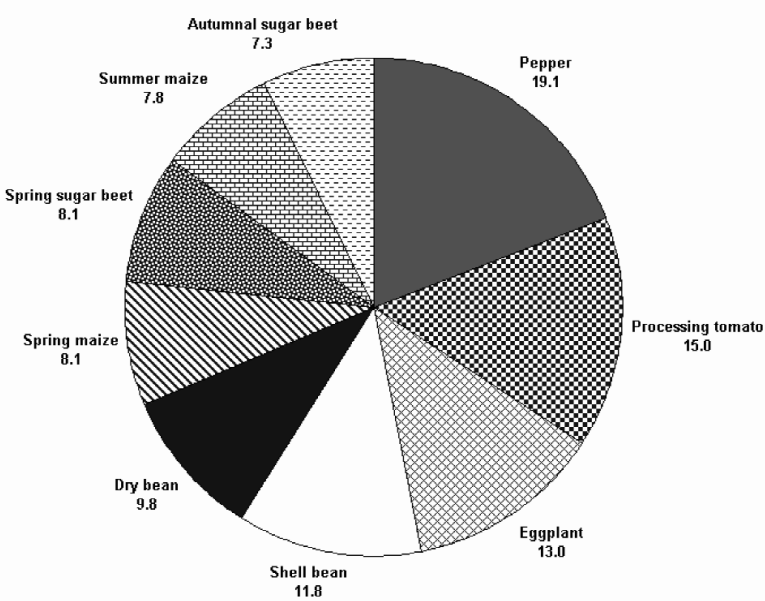

Figure 5. Values of the irrigation volumes allocation among the examined nine crops, expressed as percentage of the available total water volume of $37000 \mathrm{~m}^{3}$.

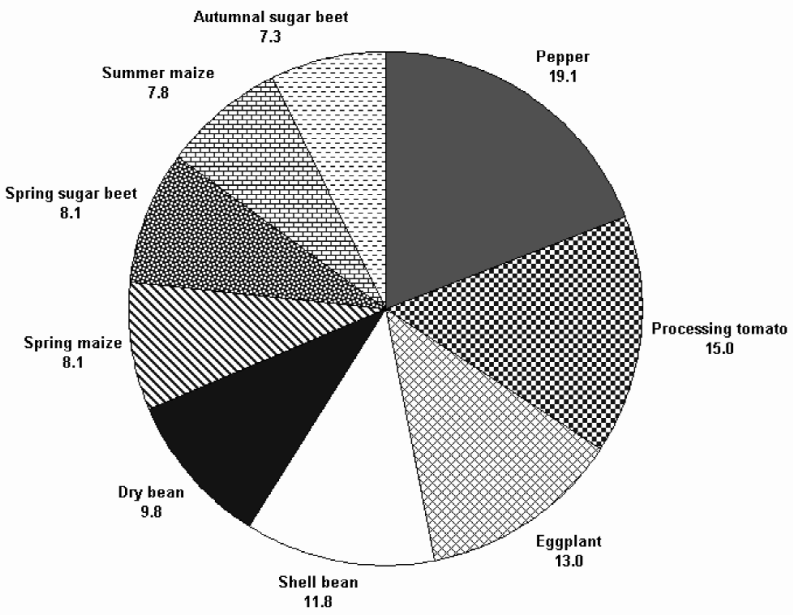

Figure 6. Seasonal irrigation volumes allocated among the crops expressed as percentage of the maximum evapotranspiration (ETM) recorded over the crop cycle of each crop. 


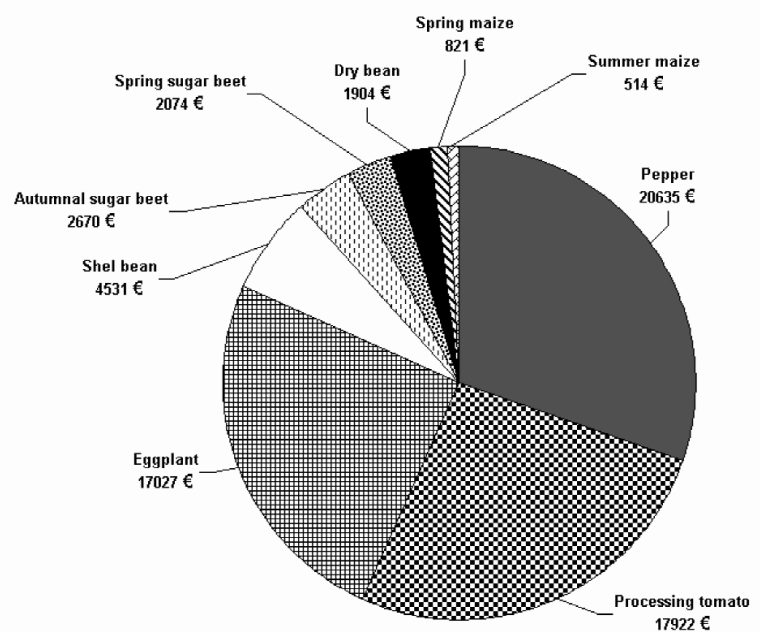

Figure 7. Value of Production less the fixed and variable costs corresponding to each crop.

for, respectively, summer and spring maize, and for autumnal and spring sugar beet. These differences are due to the dissimilar amount of the available water in the environment used by the different crops and to the crop species. Moreover, the irrigation volumes of the vegetable crops vary from 7061 to $4374 \mathrm{~m}^{3}$ ha $^{-1}$ but the percentage of $\mathrm{ETM}_{\mathrm{lr}}$ remains equal to $100 \%$ (Fig. 3).

Through the model, the variability of the $\mathrm{VP}_{\text {lic }}$ has been evaluated for the nine studied crops. The VPlic values, reported in Figure 7,

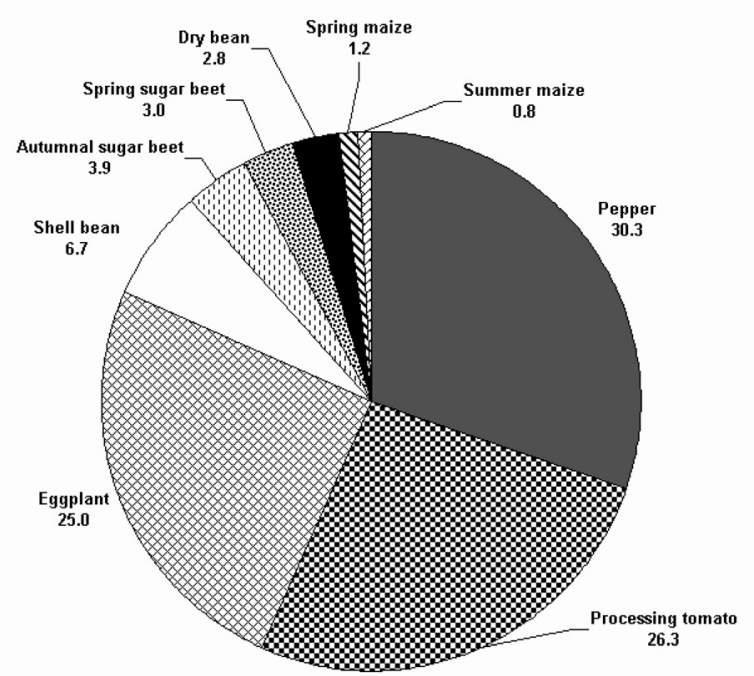

Figure 8. Value of Production less the fixed and variable costs corresponding to each crop as percentage of the total (68098 euro). have been higher for the vegetable crops, except for dry bean, lesser for autumnal and spring sugar beet.

To make the $\mathrm{VP}_{\text {lic }}$ values comparable in time and released from factor of time such as market prices, their values have been converted in percent of the total $\mathrm{VP}_{\text {lic }}$ (Fig. 8). These percentage values have been equal to 30.3 for pepper; 26.3 for processing tomato; 25 for eggplant; 6.7 for shell bean; 3.9 for autumnal sugar beet; 3.0 for spring sugar beet; and 0.8 for summer maize; resulting major for the vegetable crops as observed for the seasonal irrigation volumes reported in Figure 3.

\section{Conclusions}

To know the economically more convenient irrigation water volume distribution among different herbaceous crops such as, pepper, processing tomato, eggplant, shell and dry bean, autumnal and spring sugar beet, spring and summer maize, grown in southern Italy (Policoro, MT, N. Lat $40^{\circ} 12^{\prime}$; W. Long. $16^{\circ} 40^{\prime}$ ), a non linear mathematical model written in GAMS has been employed. To apply the mathematical model, the parameters of the yield response to seasonal irrigation volumes function of Mitscherlich equation, as modified by Giardini and Borin, have been calculated. Field experimental data gathered in different years for the nine crops previously cited have been employed, to calculate these parameters. In this example of model application, it has been hypothesized to assign a surface of one hectare to each crop considered, realizing a total surface of nine hectares. Varying the amount of irrigation water volume to allocate to the examined total surface of nine hectares and applying the model, the best water partition among the considered crops has been realized, finding out in this way the total water volume to which corresponds the maximum Value of Production less the fixed and variable irrigation costs $\left(\mathrm{VP}_{\mathrm{lic}}\right)$. Moreover, the best seasonal irrigation volumes distribution among the different crops have been found out, also in the cases of total volumes inferior to the one of the maximum economical profit.

From the model it is possible to deduce the weight (seasonal irrigation volume for each crop/ total volume for entire surface) that each 
crop assumes within the water resource allocation for the examined surface.

The highest profit (the total $\mathrm{VP}_{\text {lic }}$ ) has been obtained irrigating the vegetable crops with seasonal irrigation volumes equal to $100 \%$ of the maximum Evapotranspiration (ETM), whereas the spring and summer maize and the autumnal and spring sugar beet with the $78 ; 62 ; 48$; and $41 \%$ of ETM, respectively.

This result proves what already observed only comparing the yield response curves studied in Southern Italy, as reported in a previous work.

However, it is important to underline the fact that the $\mathrm{VP}_{\text {lic }}$ has been computed considering the irrigation costs only; if the harvesting costs, which assume high values in vegetable crops, are also considered, the differences in profit between vegetables and other crops would be lesser.

However, hypothesizing for vegetable crops harvesting costs even high up to $50 \%$ of the Value of Production (VP), the Value of Production less the irrigation and harvesting costs for the vegetables are still higher than the other crops examined.

This work has confirmed the validity of the model that can be, thus, a useful instrument for scheduling water resource both at farm and district level. Indeed, giving the parameters of equation of yield response to irrigation to the model, with the surface and number of crops to irrigate, and the amount of available water, the model works out the best water allocation and the surface to assign to each crop to obtain the maximum profit with the minimum water use. The optimal total volume of $37000 \mathrm{~m}^{3}$ calculated through the model, inferior of $8600 \mathrm{~m}^{3}$ with respect to $45600 \mathrm{~m}^{3}$, corresponding to $100 \%$ of the ETM of all nine crops considered, allows a water saving of about $19 \%$, which is of great importance keeping in mind the actual problem of the "water" in the world.

The GAMS procedure can also be adopted to study the allocation of other factors dividable in doses and that influence the production such as the fertilizers.

\section{Acknowledgements}

We would like to thank Mario Alberto Mastro for his concrete collaboration and his availability during the preparation of this paper.

\section{References}

Al-Weshah R.A. 2000. Optimal use of irrigation water in the Jordan Valley: a case study. Water Resources Management, 14:327-338.

Boguslawski E.V. 1981. Ackerbau.Grundlagen der Pflanzenproduktion, 46-52, DLG-Verlag, Frankfurt.

Brooke A., Kendrick D., Meeraus A. 1992. GAMS: A user's guide. Scientific Press.

Caliandro A., De Caro A. 1973. Effetti di diversi volumi stagionali d'irrigazione sulla coltura del peperone. Ann. Fac. Agr., Univ. Bari, 26:625-651.

Caliandro A., De Caro A. 1973. Variazioni delle rese del la barbabietola da zucchero in semina primaverile in funzione del volume stagionale di irrigazione. Scien. Tecn. Agr., 13:3-4, Pubi. No. 2, 71-90.

Caliandro A., Tarantino E., De Caro A., Rubino P., Mastro A. 1983. Consumi idrici del mais in prima coltura. L'Inform. Agr., 39:11:25011-25015.

Cavazza L. 1967. Determinazione della variazione delle rese produttive in funzione del volume stagionale di irrigazione. Quad. Ric. Scient., 19-20 ottobre, 50:37-56.

Cucci G., Caliandro A., Catalano M., Mastro M.A. 1989. Risposta produttiva della barbabietola da zucchero autunnale a diversi regimi irrigui ed epoche di semina in ambiente meridionale. L'Inforni. Agr., 45, 22:67-72.

Giardini L., Borin M. 1985. Proposta metodologica per l'esame delle curve di risposta produttiva all'irrigazione. Riv. di Agronomia, 4:239-250.

Gorantiwar S.D., Smout I.K. 2006. Model for performance based land area and water allocation within irrigation schemes. Irrig Drainage Syst, 20:345-360.

Hsiao T.C. 2005. A systematic and quantitative approach to improve water Use Efficiency in agriculture. Proceedings of Water, Land and Food Security in Arid and Semiarid Regions, 6-11, Valenzano, Bari, September 2005.

Linsalata D., De Caro A. 1974. Influenza del volume stagionale d'irrigazione sulla produzione del la melanzana. Quad. Ric. Scient., 99:3-13.

Mitscherlich E.A. 1909. Das Gesetz des Minimum und das Gesetz des abnehmenden Bodenertrags. Lanwirtsch, Jarab, 38:537-552.

Quaglietta Chiarandà F., Barbieri G., Monotti M., Montemurro P., Spanu A., Venezian Scarascia M.E., Cuocolo L., Guiducci M., Losavio N., Martorella A., Pruneddu G. 1982. Effetto di volumi irrigui crescenti sulla produzione di un ibrido di mais da granella in semina estiva in diverse località del Centro-sud. Ann. ISC, Suppl. vol. 13, 1:95-120.

Reca J., Roldan J., Alcaide M., Lopez R., Camacho E. 2001. Optimization model for water allocation in deficit irrigation systems I. Description of the model. Agricultural Water Management, 28:103-116.

Rubino P., Tarantino E. 1981. Influence of irrigation regime on seed yield of Phaseolus Vulgaris L. in Southern Italy. Acta Horticult., 111:195-202. 
Rubino P., Vannella S. 1989. Esame comparative tra alcuni modelli matematici per lo studio della risposta produttiva del pomodoro all'irrigazione. Irrig. e Dren., 4:142-146.

Shangguan Z., Shao M., Horton R., Lei T., Qin L., Ma J. 2002. A model for regional optimal al location of irrigation water resources under deficit irrigation and its applications. Agricultural Water Management, 52:139-154.

Steduto P. 1996. Water use efficiency. In: Pereira L.S., Feddes R.A., Gilley J.R., Lessafre B. (eds.): Sustain- ability of irrigate agriculture. NATO ASI Series E: Applied Sciences Kluwer Academic Publ., Dordrecht, 193-209.

Tarantino E., Rubino P., Montemurro P. 1983. Influenza del regime irriguo sulle caratteristiche della produzione del fagiolo da sgranare per il consumo fresco (tipo borlotto) nell'Italia meridionale. Irrigazione, 29:21-27.

Vannella S. 1982. Considerazioni su una funzione adattante le curve rese Volumi e significato biologico dei parametri di una sua trasformata. Ann. Fac Agr., Univ. Bari, 32:769-776. 